ANUVA Volume 2 (4): 393-398, 2018

Copyright (02018, ISSN: 2598-3040 online

Available Online at: http://ejournal.undip.ac.id/index.php/anuva

\title{
Menyoal Pentingnya Layanan Informasi dan Referensi di Perguruan Tinggi Indonesia
}

\author{
Yanuar Yoga Prasetyawan ${ }^{1^{*}}$ \\ ${ }^{1}$ Program Studi Ilmu Perpustakaan, Fakultas Ilmu Budaya, Universitas Diponegoro, \\ Jl. Prof. Soedarto, SH, Kampus Undip Tembalang, Semarang, Indonesia 50275
}

*Korespondensi: yanuaryoga@ live.undip.ac.id

\begin{abstract}
Nowdays the library is not enough if it's just serving. The library must have added value. In addition to its main task of providing information resources, libraries must be more proactive, libraries are able to provide education, teaching, and guidance in an effort to meet the information needs of users. In order to meet these demands, the library needs to manifest a service called information and reference services. Information and reference services are information consulting activities in which librarian staff recommend, interpret, evaluate, and use information resources to help users meet their information needs. In this article, we will review the importance of an information and reference service in the academic library.
\end{abstract}

Keyword: refrence and information services; academic library; information explotion

\begin{abstract}
Abstrak
Perpustakaan kini tidak cukup jika hanya sekedar melayani. Perpustakaaan kini harus memiliki nilai tambah. Selain tugas pokoknya yaitu menyediakan sumber informasi, perpustakaan harus dapat lebih proaktif, perpustakaan mampu memberikan pendidikan, pengajaran, dan bimbingan dalam usaha pemenuhan kebutuhan informasi pemustaka. Guna memenuhi tuntutan tersebut maka perpustakaan perlu memanifestasikan sebuah layanan yang dinamakan layanan informasi dan referensi. Layanan informasi dan referensi adalah kegiatan konsultasi informasi di mana staf pustakawan merekomendasikan, mengiterpretasikan, mengevaluasi, serta menggunakan sumber daya informasi untuk membantu pemustaka memenuhi kebutuhan informasinya. Pada artikel ini akan diulas mengenai pentingnya sebuh layanan informasi dan referensi eksis di perpustakaan perguruan tinggi.
\end{abstract}

Kata kunci: layanan informasi dan referensi ; perpustakaan perguruan tinggi; ledakan informasi

\section{Pendahuluan}

Pendidikan, penelitian, dan pengabdian masyarakat merupakan tridarma perguruan tinggi yang wajib dilakukan oleh sivitas akademika termasuk dosen dan mahasiswa. Dalam pelaksanaannya ketiga kegiatan tersebut sangat memerlukan sumber referensi yang relevan (sesuai dengan kebutuhan informasi) dan kredibel (jelas kepengarangannya dan berkualitas). Perkembangan teknologi informasi dan komunikasi menjadi peluang solusi pemenuhan kebutuhan informasi. Kemudahan akses informasi kapan saja dan di mana saja dengan memanfaatkan teknologi informasi dan komunikasi merupakan dampak dari perkembangan tersebut.

Perkembangan teknologi informasi dan komunikasi jika dikaji lebih lanjut, ternyata perihal tersebut tidak hanya menjadi peluang bagi pemenuhan kebutuhan informasi, namun juga menjadi ancaman. Ancaman tersebut terjadi karena dengan memanfaatkan perkembangan teknologi informasi dan komunikasi setiap penggunanya memiliki hak untuk mengakses sekaligus mereproduksi informasi. Karena hal tersebut 
maka informasi yang tersedia dengan bantuan teknologi informasi dan komunikasi menjadi teramat banyak. Fenomena paparan informasi dari segala arah tersebut lebih popular dengan istilah ledakan informasi atau information overload. Ledakan informasi mengakibatkan para pencari informasi mengalami kesulitan untuk menaksir kredibilitas informasi. Sulitnya menaksir kredibilitas informasi terjadi dikarenakan kemungkinan informasi diproduksi oleh bukan individu yang memiliki kesesuaian kompetensi dengan informasi yang diproduksi. Fenomena tersebut mendorong perlunya bagi para sivitas akademika untuk memiliki asisten atau pemandu penelusuran informasi. Dalam kondisi inilah seharusnya perpustakaan hadir sebagai kompas atau pemandu arah bagi penelusur informasi.

\section{Layanan Referensi Sebagai Sebuah Solusi dari Ledakan Informasi}

Perpustakaan merupakan tempat yang tepat untuk mengatasi solusi dari masalah yang diuraikan di atas, karena di dalam perpustakaan tersedia layanan yang memberikan fasilitas asistensi dalam mengidentifikasi sumber informasi baik tercetak maupun sumber informasi elektronik yang relevan dan sesuai dengan kebutuhan informasi, asistensi dan instruksi baik fomal maupun informal untuk dapat mengoptimalkan pemanfaatan layanan yang tersedia pada perpustakan, serta memberikan informasi yang up to date dan faktual setiap saat dibutuhkan, layanan yang dimaksud adalah layanan referensi (Thomas Galvin dalam Bopp dan Smith: 2011).

Fasilitas yang tersebut dalam layanan referensi dikemas dalam berbagai jenis layanan referensi (Bopp dan Smith: 2011) antara lain: Readers' Advisory yaitu layanan pemberian rekomendasi bacaan bagi pemustaka, Ready Reference merupakan pemberian jawaban singkat terhadap pertanyaan yang sangat spesifik, Research Consulting merupakan asistensi kegiatan penelitian untuk menjawab pertanyaan dalam penelitian, Subject Specialists penempatan spesialis bidang tertentu sebagai staf pustakawan referensi, Bibliographic Verification and Citation merupakan layanan identifikasi dan verifikasi sitasi sebuah sumber informasi serta membantu mencarikan sumber informasi lain yang sejenis yang mensitasi sumber informasi yang sama, Interlibrary Loan and Document Delivery merupakan layanan pinjam antar lembaga informasi, Instruction merupakan layanan pemberian instruksi baik secara langsung maupun tidak langsung dalam memanfaatkan sumber daya informasi yang tersedia, Literacy Programs yaitu memberikan kegiatan pelatihan literasi informasi agar para pemustaka mempunyai kemampuan untuk mampu mengidentifikasi informasi apa yang diperlukan, memahami bagaimana informasi diorganisasikan, mengidentifikasi sumbersumber informasi yang terbaik untuk memenuhi kebutuhan informasi, mencari sumber-sumber informasi, mengevaluasi sumber-sumber informasi secara kritis, dan berbagi informasi (ACRL: 2000).

\section{Formulasi Layanan Prima dalam Layanan Referensi}

Mempertimbangkan begitu kompleks serta beragamnya jenis layanan yang diberikan oleh layanan referensi, maka dibutuhkan agen atau aktor penggerak laju roda layanan refernsi yang memiliki beberapa kualifikasi kompetensi (RUSA: 2003) berikut ini: 
1. Mengakses (Access)

Fokus utama kompetensi ini adalah pemahaman pustakawan referensi terhadap kebutuan informasi dan perilaku pengguna informasi serta mengembangkan kemampuan untuk memenuhi kebutuhan informasi pemustaka secara efektif. Kompetensi mengakses mencakup kemampuan untuk mengatasi overload informasi pengguna, mengakui pentingnya waktu dan kenyamanan pengguna, mengidentifikasi dokumen dengan bekal pengetahuannya melalui bibliorafi dan indeks, kemampuan untuk mengidentifikasi dan memberikan solusi terhadap informasi yang sukar dimengerti, kemampuan untuk menilai informasi yang tepat bagi pemustaka dan meminimalisir hambatan dalam layanan.

2. Pengetahuan Dasar (Knowledge Base)

Pengetahuan dasar yang wajib dimiliki pustakawan layanan referensi adalah:
a. Struktur sumberdaya Informasi
b. Pengetahuan tentang alat-alat informasi
c. Pola pencarian informasi dan perilaku pemustaka
d. Teknik berkomunikasi
e. Pengaruh teknologi pada struktur informasi
f. Hak cipta dan hukum kekayaan intelektual

Ketrampilan yang harus juga dimiliki oleh pustakawan adalah teknik penilaian pemahaman, metode belajar berkesinambungan, penerapan pengetahuan untuk praktek, serta bagaimana merencanakan dan menerapkan pengembangan layanan bagi pemustaka. Pengetahuan ini diperoleh sebagai bagian dari pendidikan dasar profesi, yang lebih penting adalah pengetahuan pustakawan harus terus menerus diperbaharui, oleh karena itu kompetensi ini adalah bagian yang menetukan tujuan dan strategi serta bentuk layanan referensi yang dilayankan.

3. Pemasaran, Kepekaan, Menginformasikan (Marketing, Awarness, Informing)

Sebuah proses perencanaan sangat penting untuk mengidentifikasi dan mempromosikan layanan kepada pemustaka, kegiatan ini merupakan sebuah bentuk pemetaan mengenai cara dan metode layanan informasi yang akan disampaikan.

4. Kolaborasi (Collaboration)

Seorang pustakawan layanan referensi harus memiliki kemampuan untuk berkolaborasi dengan profesional lain di luar pustakawan untuk menunjang pengembangan layanan referensi atau bahakan berkolaborasi dengan pemustaka dalam memecahkan permasalahan kebutuhan informasi pemustaka.

5. Evaluasi dan Penilaian Sumber Daya Informasi dan Jasa

Konsistensi penilaian sumber daya (baik manusia maupun barang/ informasi) dalam konteks kebutuhan pengguna sangat penting untuk menjaga layanan informasi tetap relevan. Unsur yang paling penting dalam layanan informasi adalah staf yang menyediakan layanan tersebut. 
Selain tuntuan untuk memiliki kompetensi tersebut di atas, seorang putakawan referensi dituntut untuk dapat menyampaikan layanan dengan baik, agar dapat memenuhi ekspektasi pemustakanya. Pustakawan dituntut untuk berperilaku yang menyenangkan dan kooperatif ketika menghadapi pemustaka. Berikut ini beberapa pedoman perilaku kinerja penyedia layanan referensi (RUSA: 2010) yang direkomendasikan oleh Reference and User Services Association:

1. Approachability; pustakawan referensi nampak bersahabat dan bersedia untuk membantu pemustaka dalam memenuhi kebutuhan informasi

2. Interest; antusiasme pustakawan referensi tinggi dalam memberian layanannya

3. Listening and Inquiring ; pustakawan mampu memahami dengan baik terhadap pertanyaan yang diajukan kemudian mampu mengidentifikasi kebutuhan informasi pemustaka, sehingga pemustaka merasa menjadi mudah dalam memenuhi kebutuhan informasinya.

4. Serching; pustakawan memiliki kemampuan yang dapat diandalkan untuk menelusur informasi yang dibutuhkan pemustaka secara akurat dan relevan.

5. Follow-Up; pustakawan mampu mengenali apakah pemustaka sudah puas atau belum terhadap hasil pencarian informasi yang diberikan.

Formulasi kualifikasi kompetensi dengan perilaku kinerja tersebut di atas merupakan ramuan yang tepat untuk menciptakan sebuah layanan referensi yang prima. Layanana referensi prima ini patut didapatkan oleh seluruh pemustaka terlebih lagi bagi pemustaka peneliti dalam tulisan ini adalah dosen dan mahasiswa, karena kebutuhan informasinya yang sangat kompleks dan spesifik, dibutuhkan pustakawan referensi yang sangat kooperatif mempunyai passion yang tinggi untuk membantu pemustaka peneliti menggali lebih dalam kebutuhan informasi yang benar-benar dimaksudkan, diutarakan, dan diinginkan oleh pemustaka peneliti.

Dengan senantiasa berusaha memenuhi ekspektasi pengguna perpustakaan pada umumnya dan pemustaka peneliti pada khususnya, maka perpustakaan akan mendapatkan komunitas pengguna perpustakaan yang puas karena kebutuhan informasinya terpenuhi dengan baik, kemudian pemustaka tersebut akan berpotensi untuk menarik pengguna potensial lain (melalui kegiatan getok tular) untuk mau memanfaatkan layanan referensi.

\section{Pustakawan Referensi Sebagai Asisten Pemustaka Peneliti}

Telah dijelaskan dalam tulisan sebelumnya pemustaka peneliti dalam tulisan ini adalah dosen dan mahasiswa yang memiliki tugas pokok tridarma perguruan tinggi. Tidak semua pemustaka peneliti memiliki latar pendidikan ilmu perpustakaan atau memiliki library skill (kemampuan memanfaatkan sumber daya informasi), maka dalam kondisi tersebut pustakawan seharusnya mampu hadir sebagai pemandu peustaka peneliti dalam menelusur informasi guna memenuhi kebutuhan informasi mereka. Pustakawan referensi ketika menjalankan tugasnya pada hakikatnya bukan hanya melayani dengan memberikan semua kebutuhan informasi, namun lebih dari itu, pustakawan referensi harus mampu 
memberikan kontribusi terhadap pemustaka yang dilayani dengan cara menjadi asisten dan kontributor bagi pemustaka yang dilayaninya.

Perpustakaan perguruan tinggi memiliki peran sebagai pengajar bagi masyarakat akademik. Masyarakat akademik yang paling membutuhkan bimbingan dan arahan dalam penelusuran informasi, utamanya adalah mahasiswa. Mahasiswa membutuhkan pemandu untuk mengatur informasi yang ada disekelilingnya. Mahasiswa memiliki pengalaman yang sedikit dalam mengakses informasi mengenai tugas yang didapatkannya dari dosen, lain halnya dengan dosen tersebut dia lebih berpengalaman dalam mengakses informasi mengenai subjek yang diberikan kepada mahasiswa, sehingga terjadi ketidaktemuan antara ekspektasi dosen tersebut dengan tugas atau tulisan yang dihasilkan oleh mahasiswa. Melalui peran pustakawan referensi sebagai asisten pemustaka peneliti, diharapkan dapat menghilangkan kesenjangan perihal tersebut.

Tidak dapat dipungkiri lagi, disadari maupun tidak disadari, sekarang perpustakaan bukan lagi satusatunya pusatnya informasi. Informasi sekarang ada di mana-mana, mudah serta murah mendapatkannya. Akses untuk mendapatkan informasi banyak cara dan macamnya. Karena hal tersebut maka kini pustakawan treferensi dituntut untuk proaktif dalam memberikan layanan referensi dan informasi. Sikap proaktif ini seharusnya tertanam dalam benak dan perilaku pustakawan referensi. Tertanam dalam benak pustakawan referensi bahwa setiap pemustaka membutuhkan bantuannya untuk menelusur informasi, karena tidak semua pemustaka memiliki kemampuan penelusuran informasi yang baik. Sikap proaktif juga ditunjukan dengan perilaku pustakawan referensi dengan cara selalu mencari pemustaka untuk dibantu dalam menelusur informasi (Hickok: 2012). Sikap proaktif tersebut akhirnya juga memiliki dampak yang baik bagi pengubahan stereotype negatif pustakawan. Dengan sikap tersebut maka profesi pustakawan memiliki wajah baru yang tidak lagi negatif namun sebaliknya.

Pustakawan layanan referensi ketika menjalankan tugasnya pada hakikatnya bukan hanya melayani dengan memberikan semua kebutuhan informasi, namun lebih dari itu, pustakawan referensi harus mampu memberikan kontribusi terhadap pemustaka yang dilayani dengan cara menjadi asisten dan kontributor bagi pemustaka yang dilayaninya.

Ujung tombak layanan referensi berada pada sumber daya manusia pustakawan referensi tersebut, maka saran yang dapat diajukan dalam tulisan ini adalah, dibutuhkan gairah/ passion yang tinggi untuk menjadi seorang pustakawan referensi, karena dengan passion yang tinggi pustakawan akan terus termotifasi untuk senantiasa mengembangkan kemampuan dan keahliannya dalam melayani pemustakanya serta berusaha untuk memenuhi kualifikasi seorang pustakawan referensi dan berlaku ramah bersahabat sesuai engan anjuran tingkah laku seorang pustakawan referensi ketika meayani pemustakanyasehingga akan tercipta layanan referensi prima.

Dukungan dari manajemen untuk menciptakan kader-kader pustakawan yang selalu bersemangat untuk senantiasa belajar dan mengembangkan kompetensi diri sangat dibutuhkan untuk mencetak 
pustakawan-pustakawan yang unggul dan berdaya guna tinggi sehingga akan tercipta layanan-layanan perpustakaan yang prima dan utama bagi pemenuhan kebutuhan informasi pemustaka yang dilayani.

\section{Simpulan}

Kegiatan Tridharma Perguruan Tinggi merupakan kegiatan ilmiah yang membutuhkan suplay dan dukungan bahan kajian referensi ilmiah. Keterbatasan yang dimiliki sivitas akademika perguruan tinggi dalam menelusur bahan kajian referensi ilmiah karena minimnya library skill, menjadi alasan bahwasanya mereka masih membutuhkan kompas atau penunjuk arah di era informasi kini. Meskipun perkembangan teknologi dan informasi yang kian pesat, sehingga mengakibatkan mudahnya seseorang untuk memperoleh informasi, namun karena adanya information overload informasi tersebut menjadi kabur, tidak nampak oleh pencari informasi kredibilitas dan relvansinya. Perihal tersebutlah yang menguatkan pentinya eksistensi layanan referensi dan informasi di perguruan tinggi Indonesia.

\section{Daftar Pustaka}

ACRL. (2000). The Information Literacy Competency Standards for Higher Education. Januari 06, 2016. http://www.ala.org/acrl/standards/informationliteracycompetency

Bopp, Richard E. dan Smith, Linda C. (2011). Reference and information services : an introduction. California: Libraries Unlimited.

Cassel, Kay Ann, and Hiremath, Uma. (2009). Reference and Information Services in the $21^{\text {st }}$ Century: an introduction. London: Facet Publishing

Hickok, John. (2012). New Development and Inovations in Academic Libraries: How to make your library effective. Februari 01, 2016. http://photos.state.gov/libraries/vietnam/8621/pdf-forms/HickokLibrary Innovations-May2012.pdf

Kern, M. Kathleen. (2009). Virtual Reference Best Practices : Tailoring Services to Your Library. Chicago: ALA

RUSA. (2010) Guidelines for Behavioral Performance of Reference and Information Service Providerss. Januari 06, 2016. http://www.ala.org/rusa/resources/guidelines/guidelinesbehavioral

RUSA. (2003, 26 Januari). Professional Competencies for Reference and User Services Librarians. Januari 06, 2016. http://www.ala.org/rusa/resources/guidelines/professional

RUSA. (2012). Using Primary Sources on the Web. Januari 06, 2016. http://www.ala.org/rusa/resources/usingprimarysources\#evaluating 